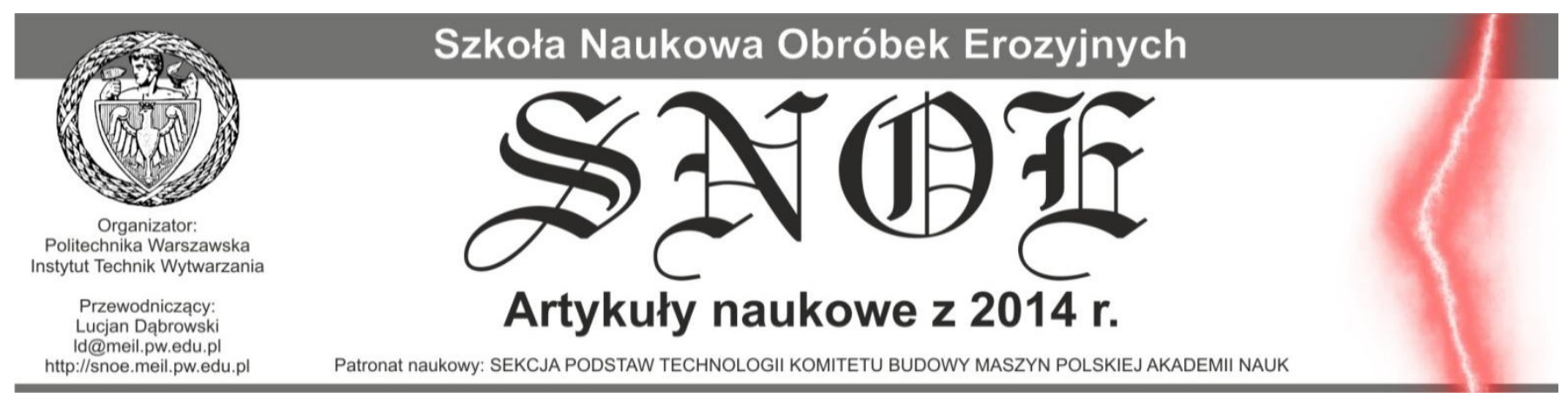

Wpływ strategli powlerzchniowej obróbki laserowej na jej efektywność

\title{
Influence of laser surface treatment strategy on Its efficlency
}

\author{
JOANNA RADZIEJEWSKA \\ JACEK WIDŁASZEWSKI
}

Przedstawiono wyniki badań eksperymentalnych procesu hartowania laserowego stali 45 . Do badań wykorzystano laser Nd:YAG pracujący w trybie ciągłym. Przeprowadzono analizę wpływu strategii obróbki na jej efektywność. Energochłonność procesu analizowano na podstawie wielkości strefy zahartowaniej uzyskanej w wyniku zastosowania pojedynczego przejścia wiązki laserowej, skanowania powierzchni i obróbki $z$ oscylacyjnym ruchem wiązki względem materiału. Stwierdzono znaczące zwiększenie efektywności procesu w warunkach nagrzewania oscylacyjnego.

SŁOWA KLUCZOWE: obróbka laserowa, hartowanie powierzchniowe, oscylacje.

Laser hardening of the 45 carbon steel using Nd:YAG laser under $C W$ operation mode, with linear and oscillatory laser beam motion perpendicular to the feed velocity (laser weaving) is analyzed in the paper. Application of laser weaving resulted in significant improvement in energy efficiency of the process, as compared to the simple linear motion and meander scanning.

KEYWORDS: laser processing, laser hardening, laser weaving

\section{Wstęp}

Wiązka laserowa ma unikatowe właściwości jako źródło ciepła dla różnych metod powierzchniowej obróbki materiałów i elementów konstrukcyjnych. Nagrzewanie powierzchni może być precyzyjnie sterowane poprzez zmiany wartości

\footnotetext{
* Dr hab. inż. Joanna Radziejewska, jradz@ippt.pan.pl, dr inż. Jacek Widłaszewski, Jacek.Widlaszewski@ippt.pan.pl
}

mocy, rozkładu gęstości strumienia ciepła, obszaru oddziaływania i przebiegu czasowego. Możliwość przemieszczania dobrze określonego strumienia ciepła z zadaną prędkością względem materiału pozwala na uzyskiwanie szybkiego nagrzania, a następnie chłodzenia z prędkością przekraczającą $1000^{\circ} \mathrm{C} / \mathrm{s}$, co jest wykorzystywane do hartowania materiałów.

Przy laserowej obróbce materiałów tradycyjnie stosowane jest przemiatanie powierzchni obrabianej wiązką z zadaną prędkością posuwową $\mathrm{v}_{f}$. Dodatkowa oscylacyjna składowa ruchu plamki laserowej, w kierunku prostopadłym do prędkości posuwowej, jest wprowadzana między innymi przy spawaniu laserowym dla poprawiania wytrzymałościowych cech złączy [1]. Taki sposób nagrzewania jest w niniejszej pracy nazywany nagrzewaniem oscylacyjnym.

W badaniach nad hybrydową laserowo-mechaniczną obróbką powierzchniową stali 304 stwierdzono znacząco większą objętość strefy materiału przetworzonego z udziałem nagrzewania oscylacyjnego w porównaniu do nagrzewania bez oscylacji [2], [3].

Zagadnienie efektywności wykorzystania energii wiązki laserowej jest intensywnie analizowane w procesach spawania laserowego [4-8]. Stąd, celowe wydaje się nawiązanie do stosowanej już metodologii i opisu ilościowego badając wpływ nagrzewania oscylacyjnego na objętość strefy wpływu ciepła przy innych rodzajach obróbki laserowej.

Do charakteryzowania procesów spawania laserowego wykorzystywany jest parametr efektywności topienia (w języku angielskim „melting efficiency”), który definiuje się [5], [7] jako: 


$$
\eta_{m}=\frac{q_{m}}{q_{a}}
$$

gdzie: $q_{m}$ jest energią potrzebną do uzyskania stopienia materiału (lub materiałów), $q_{a}$ jest energią przejętą (zaabsorbowaną) przez materiał (materiały) od wiązki laserowej użytej w spawaniu.

Energia $q_{m}$ składa się z ciepła potrzebnego do podniesienia temperatury materiału (materiałów) oraz ciepła zmiany stanu skupienia. Różnica $q_{a}-q_{m}$ jest energią potrzebną do pokrycia strat wynikających z dyfuzji ciepła do otoczenia jeziorka spawalniczego drogą przewodnictwa, promieniowania i konwekcji. Według takiego podejścia odniesienie $q_{m}$ do ciepła zaabsorbowanego $q_{a}$ sprawia, że parametr efektywności $\eta_{m}$ nie charakteryzuje w pełni sprawności energetycznej procesu, ponieważ nie ujmuje zjawisk absorpcji promieniowania przez spawane materiały i sprawności energetycznej samego urządzenia realizującego proces.

W procesach spawania objętość lub pole przekroju poprzecznego spoiny są parametrami stosunkowo łatwymi do mierzenia i jednocześnie stanowią miarodajne wskaźniki ciepła zaabsorbowanego oraz sprawności topienia materiału (materiałów) [5]. Stąd, dla porównywania zużycia energii w spawaniu, ale także przy innych procesach obróbki materiałów, można zdefiniować parametr całkowitej energii właściwej $e_{V C}\left[\mathrm{~J} / \mathrm{mm}^{3}\right]$, który mówi o całkowitej energii potrzebnej do przemiany fazowej jednostki objętości materiału.

$e_{V C}=\frac{E_{C}}{V_{p}}$

gdzie: $E_{C}$ jest całkowitą zużytą energią, $V_{p}$ jest objętością materiału, w którym zaszła przemiana fazowa.

Dla porównawczej oceny wpływu sposobu realizacji obróbki na jej wydajność można pominąć zagadnienie sprawności energetycznej samego źródła ciepła. W takim ujęciu parametr energii właściwej [6] można zdefiniować jako

$$
e_{V}=\frac{E}{V_{p}}
$$

gdzie $E$ jest energią wiązki skierowanej na powierzchnię materiału.

Jeśli objętość $V_{p}$ materiału wyrazimy przez pole powierzchni poprzecznego przekroju obszaru przetworzonego $A_{p}$ i prędkość posuwową źródła ciepła $\mathrm{v}_{f}$, to wzór na parametr energii właściwej przyjmie postać

$$
e_{V}=\frac{P}{A_{p} \mathrm{v}_{f}}
$$

gdzie $P$ jest mocą źródła (na przykład wiązki laserowej).

W niniejszej pracy uwaga jest skoncentrowana na wpływie oscylacyjnego ruchu źródła ciepła na objętość strefy wpływu ciepła (SWC) w aspekcie efektywności wykorzystywania energii. Analiza jest prowadzona dla procesu hartowania stali 45 przy użyciu wiązki lasera typu Nd:YAG.

\section{Metodyka badań}

Proces hartowania laserowego powierzchni przeprowadzono na próbkach o wymiarach $50 \times 20 \times 5 \mathrm{~mm}$, wykonanych ze stali węglowej 45 . Wykorzystano wiązkę lasera typu Nd:YAG, model RSY 150 Q, o długości fali promieniowania $1064 \mathrm{~nm}$, pracującego w trybie ciągłym. W zastosowanej konfiguracji lasera wiązka miała wielomodowy rozkład powierzchniowej gęstości mocy na przekroju poprzecznym (TEM), zbliżony do rozkładu jednorodnego.

Dla porównania efektów strategii obróbki stosowano trzy warianty ruchu wiązki laserowej względem materiału:

- W1 - pojedynczy przejazd prostoliniowy, który w laserowej obróbce materiałów jest stosowany najczęściej,

- Wosc - posuw liniowy z dodanymi oscylacjami na kierunku prostopadłym do kierunku posuwu (rys. 1a),

- Wskan - przeskanowanie powierzchni próbki poprzez meandrowe połaczenie czterech równoległych prostoliniowych ścieżek wiązki laserowej według wariantu W1, z nakładaniem się ścieżek w zakresie około $20 \%$ i bez przerywania działania wiązki przy przejściach pomiędzy ścieżkami (rys. 1b).

W przypadku wariantu Wosc ruch oscylacyjny był realizowany przez dodatkowe urządzenie umieszczone na numerycznie sterowanym stole $X Y$. Urządzenie to przemieszczało próbkę ruchem posuwisto-zwrotnym z wykorzystaniem silnika elektrycznego i układu korbowego. Amplituda oscylacji ( $a$ ) wynosiła $3 \mathrm{~mm}$, a ich częstotliwość $30 \mathrm{~Hz}$. Dodanie ruchu oscylacyjnego powoduje zwiększenie szerokości ścieżki oddziaływania laserowego o wartość amplitudy oscylacji. Wartość parametru nałożenia ścieżek w wariancie Wskan została dobrana tak, aby uzyskać takie samo pole powierzchni oddziaływania wiązki jak w wariancie Wosc.

(a)

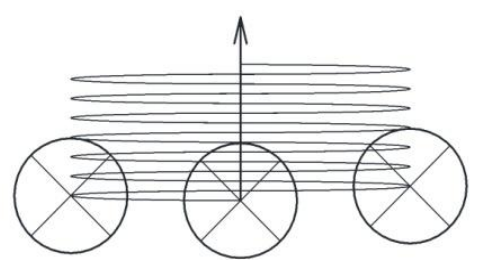

(b)

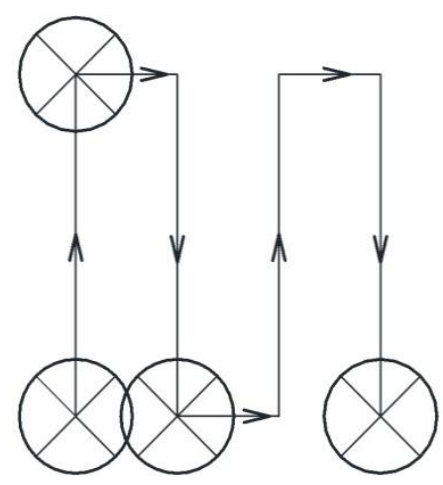

Rys. 1. Wybrane położenia plamki laserowej i jej trajektoria dla wariantów ruchu: (a) Wosc, (b) Wskan. 
W celu określenia zakresu występowania zjawiska hartowania $z$ dodanym oscylacyjnym ruchem wiązki laserowej względem materiału, przeprowadzono badania dla trzech przypadków średnicy plamki laserowej $(d)$ na powierzchni materiału: $1,1 \mathrm{~mm}, 1,8 \mathrm{~mm}$ oraz $2.2 \mathrm{~mm}$. Przy stałej mocy wiązki $175 \mathrm{~W}$, wymienionym średnicom plamki odpowiadaja wartości średnie gęstości mocy promieniowania $(q)$ : 184 69 oraz $46 \mathrm{~W} / \mathrm{mm}^{2}$. Zastosowano dwa przypadki prędkości posuwu: 300 i $150 \mathrm{~mm} / \mathrm{min}$. Badania powtórzono przy identycznych parametrach stosując pokrycie z grafitu koloidalnego, które często jest stosowane dla zwiększenia absorpcyjności powierzchni. Grubość pokrycia wynosiła od 5 do 7 mikrometrów.

Wielkość strefy zmian strukturalnych zmierzono na zgładach metalograficznych wykorzystując laserowy konfokalny mikroskop pomiarowy Keyence, model VK-X100 i jego oprogramowanie. Wyznaczono maksymalną głębokość $H_{\text {max }}$ i szerokość $B$ strefy wpływu ciepła (SWC) oraz jej pole przekroju poprzecznego $A_{p}$. Przed i po obróbce próbki były ważone w celu kontroli wpływu parowania materiału.

\section{Wyniki badań}

Efekty powierzchniowego hartowania laserowego stali dla badanych strategii prowadzenia procesu przedstawiono na rysunkach 2, 3 oraz 4 .

(a)

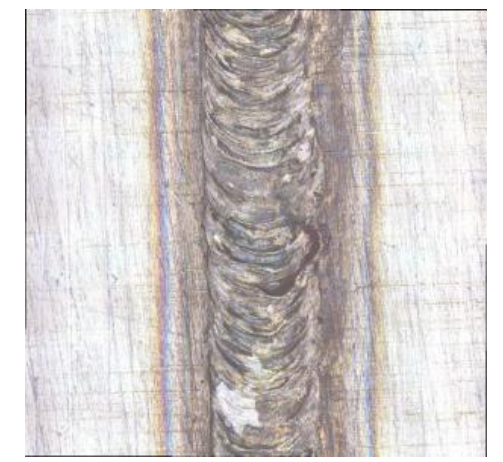

(b)

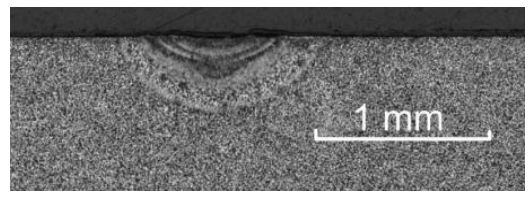

Rys. 2. Efekty oddziaływania laserowego dla wariantu W1:

(a) widok powierzchni, (b) zgład metalograficzny.

(a)

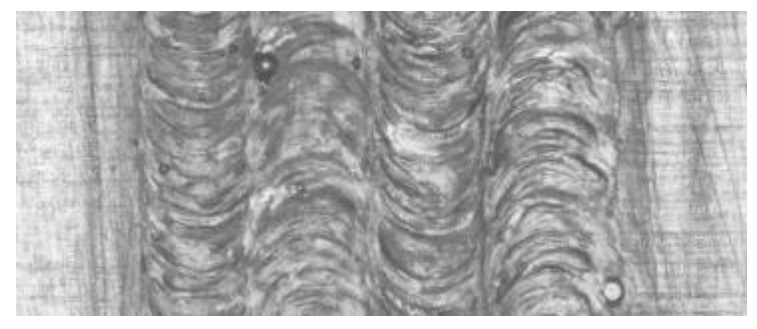

(b)

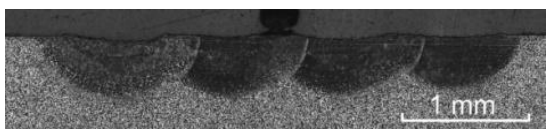

Rys. 3. Efekty oddziaływania laserowego dla wariantu Wosc: (a) widok powierzchni, (b) zgład metalograficzny. (a)

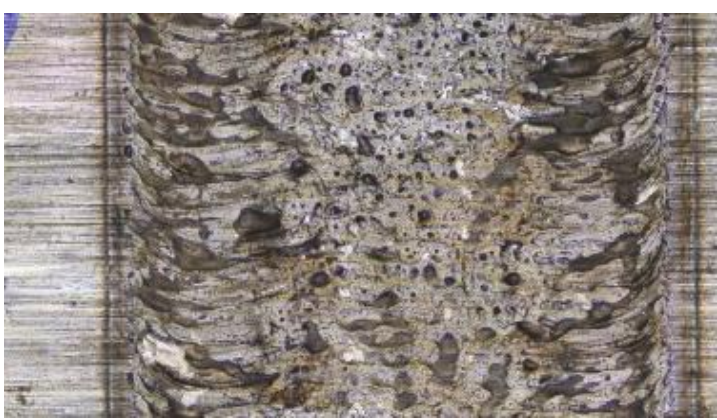

(b)

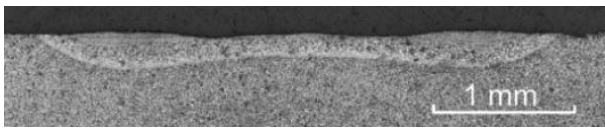

Rys. 4. Efekty oddziaływania laserowego dla wariantu Wskan: (a) widok powierzchni, (b) zgład metalograficzny.

Zawierają one fotografie stanu powierzchni próbek oraz mikrostruktury na przekroju warstwy wierzchniej po oddziaływaniu wiązką laserową o prędkości posuwu $300 \mathrm{~mm} / \mathrm{min}$, gęstości mocy $184 \mathrm{~W} / \mathrm{mm}^{2}$ i bez dodatkowej warstwy absorpcyjnej. We wszystkich przypadkach stwierdzono nadtopienie powierzchni.

Dla wariantów obróbki W1 oraz Wosc ilość dostarczonej energii oraz czas oddziaływania wiązki były jednakowe, natomiast dla wariantu Wskan całkowity czas obróbki powierzchni był czterokrotnie dłuższy, niż w pierwszym i drugim wariancie. W tabeli 1 zamieszczono wyniki pomiarów pola powierzchni przekroju SWC.

Tab. 1. Porównanie efektów obróbki laserowej.

\begin{tabular}{|c|c|c|c|c|}
\hline $\begin{array}{c}\text { Wariant } \\
\text { obróbki }\end{array}$ & $\begin{array}{c}H_{\max } \\
{[\mathrm{mm}]}\end{array}$ & $\begin{array}{c}B \\
{[\mathrm{~mm}]}\end{array}$ & $\begin{array}{c}A_{p} \\
{\left[\mathrm{~mm}^{2}\right]}\end{array}$ & $\begin{array}{c}e_{V} \\
{\left[\mathrm{~J} / \mathrm{mm}^{3}\right]}\end{array}$ \\
\hline W1 & 0,41 & 1,231 & 0,377 & 92,8 \\
\hline Wosc & 0,258 & 3,718 & 0,733 & 47,7 \\
\hline Wskan & 0,481 & 3,832 & 1,446 & 96.8 \\
\hline
\end{tabular}

W przypadku zastosowania ruchu oscylacyjnego (Wosc) pole powierzchni przekroju SWC $\left(A_{p}\right)$ jest ponad dwukrotnie większe niż dla wariantu W1, przy zastosowaniu identycznego czasu i energii liniowej procesu. Dla przypadku skanowania powierzchni (Wskan) pole powierzchni przekroju SWC jest blisko 4-krotnie większe, niż dla pojedynczej ścieżki (W1), przy ponad czterokrotnie większej energii dostarczonej. Stwierdzono większą maksymalną głębokości SWC $\left(H_{\max }\right)$, niż dla pojedynczego przejazdu prostoliniowego (W1). Efekt ten można wytłumaczyć stałym wzrostem temperatury próbki przy ciągłym nagrzewaniu kolejnych segmentów trajektorii.

Obróbka z zastosowaniem ruchu oscylacyjnego pozwoliła uzyskać dwukrotne zmniejszenie energochłonności procesu hartowania laserowego $\mathrm{w}$ stosunku do pozostałych strategii obróbki. Obróbka cieplna tej samej wielkości pola powierzchni materiału w przypadku nagrzewania oscylacyjnego (Wosc) wymagała czterokrotnie mniej energii, niż stosując skanowanie (Wskan).

Aby określić zakres parametrów obróbki laserowej, w którym opisany efekt wzrostu energetycznej efektywności obróbki występuje, przeprowadzono badania wpływu najbardziej istotnych parametrów obróbki, tj. gęstości mocy 
promieniowania $q$ i prędkości posuwu $\mathrm{v}_{f}$. Badania przeprowadzono zarówno z zastosowaniem, jak i bez pokrycia absorpcyjnego. W tabelach 2-5 przedstawiono wyniki badań.

Tab. 2. Parametry i wyniki obróbki W1 bez pokrycia grafitowego.

\begin{tabular}{|c|c|c|c|c|c|}
\hline$q$ & $\mathrm{v}_{f}$ & $H_{\max }$ & $B$ & $A_{p}$ & $e_{V}$ \\
\hline$\left[\mathrm{W} / \mathrm{mm}^{2}\right]$ & {$[\mathrm{mm} / \mathrm{min}]$} & {$[\mathrm{mm}]$} & {$[\mathrm{mm}]$} & {$\left[\mathrm{mm}^{2}\right]$} & {$\left[\mathrm{J} / \mathrm{mm}^{3}\right]$} \\
\hline 184 & 300 & 0,44 & 1,01 & 0,33 & 106 \\
\hline 69 & 300 & 0,64 & 1,45 & 0,70 & 50 \\
\hline 69 & 150 & 0,47 & 1,77 & 0,62 & 113 \\
\hline 46 & 150 & 0,48 & 2,50 & 0,90 & 78 \\
\hline
\end{tabular}

Tab. 3. Parametry i wyniki obróbki Wosc bez pokrycia grafitowego.

\begin{tabular}{|c|c|c|c|c|c|}
\hline$q$ & $\mathrm{v}_{f}$ & $H_{\max }$ & $B$ & $A_{p}$ & $e_{V}$ \\
\hline$\left[\mathrm{W} / \mathrm{mm}^{2}\right]$ & {$[\mathrm{mm} / \mathrm{min}]$} & {$[\mathrm{mm}]$} & {$[\mathrm{mm}]$} & {$\left[\mathrm{mm}^{2}\right]$} & {$\left[\mathrm{J} / \mathrm{mm}^{3}\right]$} \\
\hline 184 & 300 & 0,30 & 3.25 & 0,73 & 48 \\
\hline 69 & 300 & 0,41 & 3,37 & 1,04 & 34 \\
\hline 69 & 150 & 0,26 & 3,60 & 0,84 & 83 \\
\hline 46 & 150 & 0,43 & 3,80 & 1,23 & 57 \\
\hline
\end{tabular}

Tab. 4. Parametry i wyniki obróbki W1 z pokryciem grafitowym.

\begin{tabular}{|c|c|c|c|c|c|}
\hline$q$ & $\mathrm{v}_{f}$ & $H_{\max }$ & $B$ & $A_{p}$ & $e_{V}$ \\
\hline$\left[\mathrm{W} / \mathrm{mm}^{2}\right]$ & {$[\mathrm{mm} / \mathrm{min}]$} & {$[\mathrm{mm}]$} & {$[\mathrm{mm}]$} & {$\left[\mathrm{mm}^{2}\right]$} & {$\left[\mathrm{J} / \mathrm{mm}^{3}\right]$} \\
\hline 184 & 300 & 0,33 & 0,93 & 0,23 & 152 \\
\hline 69 & 300 & 0,42 & 1,64 & 0,52 & 67 \\
\hline 69 & 150 & 0,6 & 1,98 & 0,89 & 79 \\
\hline 46 & 150 & 0,39 & 1,98 & 0,57 & 123 \\
\hline
\end{tabular}

Tab. 5. Parametry i wyniki obróbki Wosc z pokryciem grafitowym.

\begin{tabular}{|c|c|c|c|c|c|}
\hline$q$ & $\mathrm{v}_{f}$ & $H_{\max }$ & $B$ & $A_{p}$ & $e_{V}$ \\
\hline$\left[\mathrm{W} / \mathrm{mm}^{2}\right]$ & {$[\mathrm{mm} / \mathrm{min}]$} & {$[\mathrm{mm}]$} & {$[\mathrm{mm}]$} & {$\left[\mathrm{mm}^{2}\right]$} & {$\left[\mathrm{J} / \mathrm{mm}^{3}\right]$} \\
\hline 184 & 300 & 0,26 & 3,40 & 0,66 & 53 \\
\hline 69 & 300 & 0,26 & 3,36 & 0,66 & 53 \\
\hline 69 & 150 & 0,43 & 3,57 & 1,15 & 61 \\
\hline 46 & 150 & 0,20 & 2,35 & 0,42 & 167 \\
\hline
\end{tabular}

Przy najwyższej gęstości mocy $184 \mathrm{~W} / \mathrm{mm}^{2}$ stwierdzono nadtopienie powierzchni zarówno dla obróbki z pokryciem absorpcyjnym, jak i bez. Dla gęstości mocy 69 i $46 \mathrm{~W} / \mathrm{mm}^{2}$ nadtopienia powierzchni nie występowało.

Pole powierzchni materiału, która poddana jest oddziaływaniu wiązki laserowej $\left(A_{h}\right)$ w czasie $t$, jest opisane wyrażeniami:

$$
A_{h}=d \mathrm{v}_{f} t+\pi d^{2} / 4 \text { dla wariantu } \mathrm{W} 1
$$

$A_{h}=d \mathrm{v}_{f} t+\pi d^{2} / 4+a\left(\mathrm{v}_{f} t+d\right)$ dla wariantu Wosc

Na rys. 5 przedstawiona jest zależność energii właściwej $e_{V}$ od pola powierzchni materiału, która jest poddana oddziaływaniu wiązki w czasie 1 sekundy.

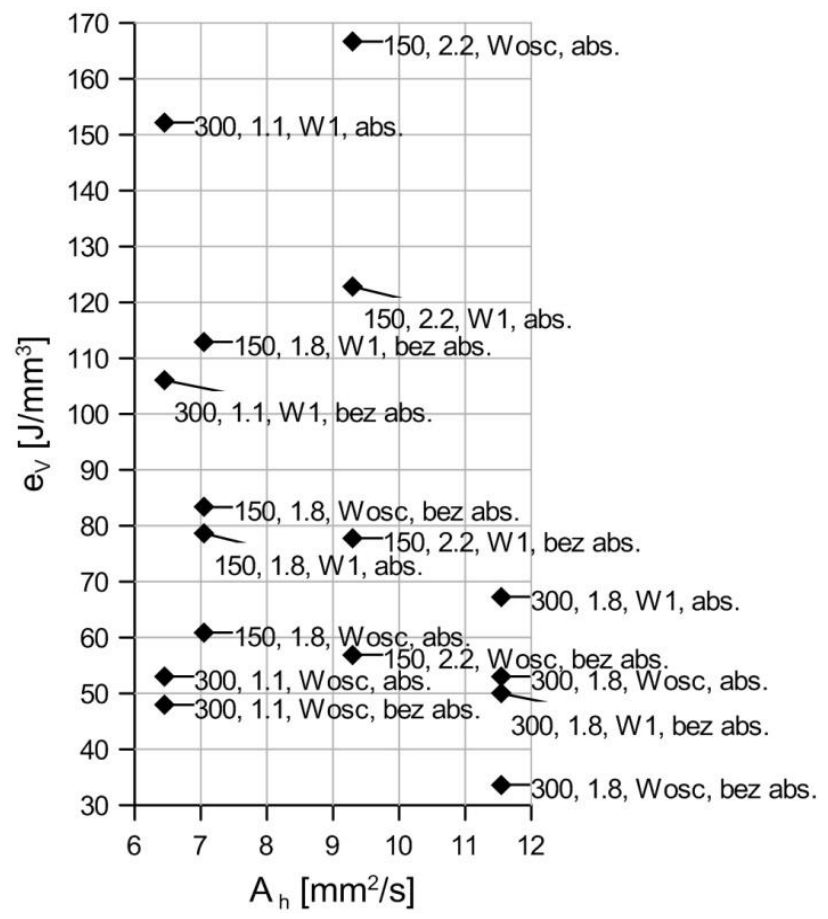

Rys. 5. Zależność energii właściwej od powierzchni poddanej oddziaływaniu wiązki w czasie $1 \mathrm{~s}$. Opisy punktów zawierają prędkość posuwową [mm/min] i średnicę plamki [mm]

\section{Dyskusja i wnioski}

Analizując przedstawione wyniki badań można stwierdzić, że laserowe hartowanie jest najkorzystniejsze w wariancie $z$ zastosowaniem ruchu oscylacyjnego. Uzyskiwana wielkość SWC jest znacząco większa w stosunku do przetapiania metodą skanowania i przetapiania na wprost przy identycznych warunkach procesu.

Wpływ ruchu oscylacyjnego można scharakteryzować za pomocą współczynnika efektywności nagrzewania oscylacyjnego ( $n \%$ ) odnoszącego pole powierzchni poprzecznego przekroju SWC ( $A_{p}$ ) otrzymane po hartowaniu z ruchem oscylacyjnym do wielkości tego pola dla ruchu prostoliniowego, przy ustalonych wartościach innych parametrów obróbki. Badania wykazały wzrost efektywności obróbki z oscylacjami $n$ wraz ze wzrostem gęstości mocy promieniowania $q$ (rys. 6 ). W przypadku występowania nadtopienia powierzchni (gęstość mocy $184 \mathrm{~W} / \mathrm{mm}^{2}$ ) współczynnik efektywności $n$ wynosił 290 i $220 \%$. Zastosowanie oscylacji spowodowało zatem względny procentowy wzrost wielkości przekroju SWC o 120\% przy braku absorbera, a przy użyciu absorbera grafitowego o 190\%.

Dla hartowania bez nadtopienia (gęstość mocy 46 i 69 $\mathrm{W} / \mathrm{mm}^{2}$ ) stwierdzono mniejszy wzrost efektywności obróbki w zakresie od 30 do $50 \%$. W jednym przypadku hartowania z zastosowaniem pokrycia grafitowego i małej gęstości mocy $46 \mathrm{~W} / \mathrm{mm}^{2}$ zaobserwowano spadek wielkości przekroju SWC. Na powierzchni próbki po procesie hartowania stwierdzono wówczas obecność nieuszkodzonej warstwy grafitu.

Dla prostoliniowego ruchu wiązki zastosowanie pokrycia absorpcyjnego zwiększyło wymiary SWC w zakresie od $10 \%$ w warunkach nadtopienia powierzchni do ponad $30 \%$ przy najniższej gęstości mocy $46 \mathrm{~W} / \mathrm{mm}^{2}$. W przypadku obróbki z oscylacjami nie stwierdzono wpływu pokrycia ab- 
sorpcyjnego na wielkość SWC. Zastosowane promieniowanie o długości fali $1064 \mathrm{~nm}$ jest stosunkowo dobrze absorbowane przez stale węglowe, szczególnie w obecności warstwy tlenkowej, która zwykle występuje na powierzchni tych materiałów. Stąd wpływ dodatkowej warstwy absorpcyjnej może być mniej zauważalny.

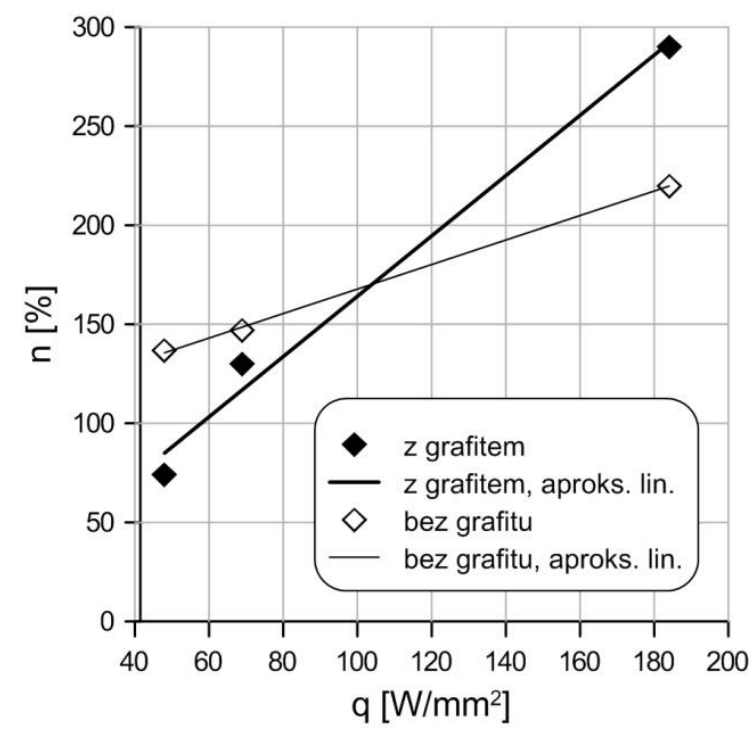

Rys. 6. Zależność współczynnika efektywności nagrzewania oscylacyjnego przy hartowaniu od gęstości mocy wiązki laserowej.

Najmniej energochłonne (najmniejsza energia właściwa $34 \mathrm{~J} / \mathrm{mm}^{3}$ ) było laserowe hartowanie $\mathrm{w}$ wariancie $\mathrm{z}$ zastosowaniem oscylacyjnego ruchu wiązki względem materiału, przy zastosowaniu prędkości posuwowej $300 \mathrm{~mm} / \mathrm{min}$, średnicy wiązki $1.8 \mathrm{~mm}$ i bez pokrycia grafitowego. W takich warunkach obróbki powierzchnia poddana oddziaływaniu wiąki laserowej w jednostce czasu była największa spośród zbadanych przypadków i nie występowało przetapianie materiału. Można stąd wnioskować, iż efekt spadku energochłonności obróbki związany jest $z$ angażowaniem stosunkowo dużej powierzchni materiału w procesie nagrzewania, co było rezultatem kombinacji ruchu oscylacyjnego, większej prędkości posuwowej $(300 \mathrm{~mm} / \mathrm{min})$ i średniej wielkości plamki laserowej $(1.8 \mathrm{~mm})$. Przy braku przetapiania materiału, takie warunki obróbki sprzyjały lepszemu wykorzystaniu ciepła na przemianę fazową.

Za wzrost efektywności hartowania laserowego z nagrzewaniem oscylacyjnym w porównaniu do nagrzewania prostoliniowego mogą być odpowiedzialne następujące czynniki:

1) inny rozkład temperatury w materiale obrabianym,

2) zmiana udziału strat ciepła związanych z przewodnictwem w głąb materiału,

3) zmiany absorpcyjności powierzchni,

4) pojawienie się dodatkowego źródła ciepła od reakcji chemicznych.

Nagrzewanie oscylacyjne inaczej kształtuje pole temperatury, co może powodować lepsze wykorzystanie ciepła do hartowania materiału. Ruch oscylacyjny można porównać do efektu rozogniskowania wiązki laserowej. Zastosowanie większego pola obróbki w pewnym zakresie gęstości mocy podnosi jej efektywność. Dzieje się to na skutek mniejszych strat energii związanych z dyfuzja ciepła w głąb materiału. Dostarczona energia jest w większym stopniu wykorzystana na podniesienie temperatury warstwy wierzchniej. Efekt ten można stwierdzić dla próbek nagrzewanych w ruchu prostoliniowym i przy gęstości mocy 69 i $46 \mathrm{~W} / \mathrm{mm}^{2}$. Mniejsza gęstość mocy promieniowania laserowego uzyskana została poprzez wzrost średnicy wiązki z 1,8 do 2,2 mm. Obróbkę prowadzono przy prędkości $150 \mathrm{~mm} / \mathrm{min}$. W tym przypadku stwierdzono większą SWC dla większej średnicy wiązki, niż dla wiązki bardziej skupionej (Tabela 2).

Teoretyczna analiza procesu przetapiania powierzchni stali 304 z zastosowaniem i bez ruchu oscylacyjnego została szczegółowo opisana w pracy [3]. Obliczenia rozkładu pola temperatur metodą elementów skończonych, przy założeniu stałej wartości współczynnika absorpcyjności powierzchni wykazały dla ruchu oscylacyjnego rozbieżności od wyników doświadczalnych, co sugeruje działanie dodatkowych czynników, nieuwzględnionych w symulacjach.

Zwiększenie efektywności obróbki może powodować podwyższona absorpcja promieniowania laserowego. Procesy chemiczne, np. utleniania, mogą zarówno być przyczyna zmian absorpcyjności powierzchni materiału, jak i źródłem dodatkowej energii $[9,10]$. Pełne wyjaśnienie mechanizmu zwiększania efektywności przy stosowaniu nagrzewania oscylacyjnego i określenie zależności tego efektu od poszczególnych parametrów technologicznych wymagają dalszych prac badawczych.

Wnioski

- Zastosowanie ruchu oscylacyjnego na kierunku prostopadłym do kierunku ruchu posuwowego zwiększa efektywność laserowego hartowania.

- Dla obróbki z nadtopieniem powierzchni stwierdzono wzrost wielkości SWC o ponad $100 \%$ po zastosowaniu ruchu oscylacyjnego w stosunku do obróbki tradycyjnej z posuwem liniowym, natomiast o 30 do $50 \%$ gdy nadtapianie nie występowało.

- Nie stwierdzono istotnego wpływu pokrycia absorpcyjnego na przebieg obserwowanego zjawiska

- Zastosowanie ruchu oscylacyjnego pozwala na znaczne zmniejszenie energochłonności procesu laserowego hartowania.

\section{Podziękowanie}

Autorzy składają podziękowanie dr inż. Tomaszowi Mościckiemu z Instytutu Podstawowych Problemów Techniki Polskiej Akademii Nauk za inspirujące dyskusje i pomoc w realizacji pracy.

\section{LITERATURA}

[1] Choi K.-D., Ahn Y.-N., Kim Ch., Weld strength improvement for Al alloy by using laser weaving method. ICALEO 2009, Paper 403.

[2] Radziejewska J., Laserowa modyfikacja właściwości warstwy wierzchniej wspomagana nagniataniem. Prace IPPT 3/2011, ISBN 978-83-89687-70-8.

[3] Mościcki T., Radziejewska J., Numerical simulation and experimental analysis of simultaneous melting and burnishing of 304 stainless steel with oscillatory laser heat source, Kovove Mater. 51, 1-8, 2013.

[4] Ready J. F. LIA handbook of laser material processing. Magnolia Publishing, 2001. 
[5] Walsh C. A., Laser welding - literature review, Materials Science and Metallurgy Department, University of Cambridge, England, 2002. http://www.msm.cam.ac.uk/phase-trans/2011/laser_Walsh_ review.pdf (dostęp 2014-11-22).

[6] Quintino L., Costa A., Miranda R., Yapp D., Kumar V., Kong C.J., Welding with high power fiber lasers - A preliminary study. Materials and Design 28 1231-1237, 2007.

[7] Tadamalle A. P., Reddy Y. P., Ramjee E., Reddy V. K., Influence of welding speed on the melting efficiency of $\mathrm{Nd}$ :YAG laser welding. Advances in Production Engineering \& Management, Volume 9, Number 3, September 2014, pp. 128 - 138. ISSN 1854 - 6250, http://dx.doi.org/10.14743/apem2014.3.182

[8] Meijer J., Laser beam machining (LBM), state of the art and new opportunities, Journal of Material Processing Technology, 149, 2-17, 2004.

[9] Antonov V., Iordanova I., Gurkovsky S., Investigation of surface oxidation of low carbon sheet steel during its treatment with Nd:Glass pulsed laser, Surface and Coatings Technology 160, 4453, 2002,

[10] Nayak S., Wang H., Kenik E.A., Anderson I.M., Dahotre N. B., Observation of exothermic reaction during laser-assisted iron oxide coating on aluminum alloy, Materials Science and Engineering $A$ 390, 404-413, 2005. 